Article

\title{
Sustainable Irrigation Using Non-Conventional Resources: What has Happened after 30 Years Regarding Boron Phytotoxicity?
}

\author{
Vanessa Mendoza-Grimón ${ }^{1,+}+\mathbb{C}$, Juan Ramón Fernández-Vera ${ }^{2,+}$, \\ Jose Manuel Hernández-Moreno ${ }^{1,+}$ and María del Pino Palacios-Díaz ${ }^{1,+ \text {,* }}$ \\ 1 Instituto de Investigación IUNAT, Grupo GEOVOL, Universidad de Las Palmas de Gran Canaria, 35001 Las \\ Palmas de Gran Canaria, Spain; v.mendozagrimon@ulpgc.es (V.M.-G.); \\ jrfernandezv@grancanaria.com (J.R.F.-V.); jhmoreno@ull.es (J.M.H.-M.) \\ 2 Laboratorio Agroalimentario y Fitopatológico del Cabildo de Gran Canaria, 35013 Arucas, Spain \\ * Correspondence: mp.palaciosdiaz@ulpgc.es; Tel.: +34-92-845-4353; Fax: +35-92-845-1142 \\ + These authors contributed equally to this work.
}

Received: 13 August 2019; Accepted: 13 September 2019; Published: 19 September 2019

check for updates

\begin{abstract}
In the Canary Islands, there is a hydrological imbalance between water consumption and renewable water availability. To provide more water resources, reverse osmosis (RO) from seawater is used. As boron (B) contents in irrigation water higher than $0.7 \mathrm{mg} / \mathrm{L}$ may be dangerous for sensible plants, B concentration in RO water (ROW) may be one of the key factors of irrigation sustainability. Some orchards have been studied after they have used drip irrigation using different water qualities for 30 years. B in water, soils, and banana leaves was determined to check the sustainability of ROW irrigation. When irrigating with ROW, in which B concentration varies between 1.0 and $1.4 \mathrm{mgB} / \mathrm{L}, \mathrm{B}$ content in banana soils seems to be stabilized at $5-7 \mathrm{mg} / \mathrm{kg}$, and no toxicity has been observed in banana leaves. The proper water and soil management used by the local farmers probably prevent the accumulation of higher B levels in soils. Considering water consumption of $9000 \mathrm{~m}^{3} \cdot \mathrm{ha}^{-1} \cdot \mathrm{year}^{-1}, 8-11$ $\mathrm{kgB} \cdot \mathrm{ha}^{-1} \cdot \mathrm{year}^{-1}$ is applied to the soil. The banana plant removes approximately $1 \mathrm{kgB} \cdot \mathrm{ha}^{-1} \cdot \mathrm{year}^{-1}$; therefore, only $10 \%$ of the total B added gets exported. This raises the following question: is it better to use membranes that are able to reduce B in ROW, increase the leaching fraction, or blend water?
\end{abstract}

Keywords: desalinated water; irrigation; reverse osmosis; banana; water resources; soil; management; boron; phytotoxicity

\section{Introduction}

The current production of desalinated water from reverse osmosis ( $\mathrm{RO})$ now stands at 65.5 million $\mathrm{m}^{3} \cdot \mathrm{day}^{-1}$. It represents about $69 \%$ of the volume of desalinated water produced. There are $395 \mathrm{RO}$ desalination plants for irrigation, producing 1.69 million $\mathrm{m}^{3} \mathrm{day}^{-1}$, which represents a percentage of $1.8 \%$ of the total volume of desalinated water [1]. A sea water desalination plant (SWDP) was built in Gran Canaria for irrigation in 1999 , which was able to produce $5.5 \mathrm{Mm}^{3} \cdot \mathrm{year}^{-1}$.

Although water quality for agriculture has been clearly defined for a long time [2], if the RO water plants are not designed to produce suited agricultural water quality, in the long run this could cause farmers some problems. This raises the following question: who is responsible for the lack of quality, and therefore who will assume the economic cost of losing the fertility of the soil? Trying to avoid possible inconveniences, the insular water authority of Gran Canaria (Consejo Insular de Aguas, CIAGC) financed an ambitious study that analyzed desalinated water by reverse osmosis, $\mathrm{RO}$ water (ROW), (alone and blended) quality effects on soils and banana production. Some of the results were published in Palacios et al, 2000 [3]. Additionally, after seven years of operation, there was a study 
taking into account sustainability aspects [4]. Nowadays, there is still a lack of specific water standards for desalinated water for the agricultural sector [5]. In this sense, the authors point out that sea water desalination plants (SWDPs) built today will be in place for decades, making post-treatment planning essential for long-term agricultural sustainability. They also remark that, when the ROW agricultural requirements are not considered at the SWDP, some minerals can be easily added by blending the ROW with other highly mineralized natural waters (with high alkalinity and hardness).

The Canary Islands, located in the Atlantic Ocean at a latitude of $28^{\circ} \mathrm{N}$, are classified as a semiarid region. Their agriculture, which has the highest percentage of irrigated agriculture vs. cultivated land in Spain (58\%), is a very effective water consumer in which localized vs. total irrigation represents the highest percentage in the country (73\%) [6]. In Gran Canaria Island there is a typical hydrological imbalance between water consumption $\left(160.5 \mathrm{hm}^{3} \cdot \mathrm{year}^{-1}\right)$ and renewable resources availability $\left(141 \mathrm{hm}^{3} \cdot\right.$ year $\left.^{-1}\right)$. Thus, more groundwater resources are being extracted than recharged and flowing out to the sea. However, as more non-conventional resources have been used, this imbalance has been decreasing. Nowadays hydrological data provide a total groundwater recharge of $46.0 \mathrm{hm}^{3} \cdot \mathrm{year}^{-1}$ and a groundwater abstraction amounting to $65.5 \mathrm{hm}^{3} \cdot \mathrm{year}^{-1}$ (based on CIAGC data from 2016 [7]). If return flows of $15.5 \mathrm{hm}^{3} \cdot \mathrm{year}^{-1}$ are considered, the groundwater reserve depletion will amount to only $4.0 \mathrm{hm}^{3} \cdot$ year $^{-1}$ (representing less than $9 \%$ of sustainable resources).

Agricultural water in Gran Canaria represents 38\% of total consumption [7], being the largest consumer of groundwater (68,3\% [8]). RO production represents $44 \%$ of total water resources, while RO provides only 14.3\% [8] of agricultural demand. The first RO plant installed in Gran Canaria for agricultural uses began its operation in 1991 [9]. ROW is accessible only to coastal agricultural areas with an altitude below 300 meters above mean sea level, due to the high cost associated with pumping this resource to the fields located at a higher altitude.

Desalinated water in the Canary Islands represents $250 \mathrm{hm}^{3} \cdot \mathrm{year}^{-1}$ [10], with RO being the most used technology. Therefore, and using the abovementioned world data, $0.9-1 \%$ of the total world production RO is produced in Canary Islands [10,11]. In this context, the use of desalinized water for irrigation, as an unconventional resource, will increase agricultural sustainability. Additionally, renewable energy consumption in $\mathrm{RO}$ must be promoted to assure environmental sustainability.

Boron is prevalent in marine waters. Boron concentration in sea water is about $4.5 \mathrm{mg} / \mathrm{L}$. Inverse osmosis membranes are less efficient at reducing B contents from the water than decreasing other ions. While RO membranes reduce salts by $99 \%$, only about $70 \%$ of total Boron from the sea water is eliminated. Thus, it is frequent to find $\mathrm{RO}$ waters with contents between 1 and $2 \mathrm{mg} / \mathrm{L}$. It is known than boron water contents higher than $0.7 \mathrm{mg} / \mathrm{L}$ may be dangerous for sensible plants, and that boron water demands careful water management practices [2]. More recent irrigation water guidelines have taken into account not only direct toxicity but also accumulation. In this sense, the USEPA [12] guidelines consider that $B$ concentration in water should remain under $0.5-0.7 \mathrm{mg} / \mathrm{L}$ for long periods of irrigation and under $2.0 \mathrm{mg} / \mathrm{L}$ for short-term irrigation. Thus, B concentration in irrigation water may be the key factor in sustainable irrigation regarding this unconventional resource.

Boron is a known phytotoxic nutrient, as B toxicity is an important disorder that can limit plant growth on soils of arid and semiarid environments throughout the world [13]. Soil characteristics and water management control boron availability to plants: factors affecting B availability in soils are solution $\mathrm{pH}$, soil texture, soil moisture, temperature, and organic matter content [14]. Thus, water management will modify plant uptake. B adsorption depends on clay content and on the presence of aluminium and iron amorphous oxides [15-17] (characteristic materials of andosols, soils frequently presented in volcanic islands like Canary Islands).

In Gran Canaria, one of most important crops being produced is bananas; in 2018, 77.253 Mkg was produced, which represented $19 \%$ of total production on Canary Island [18]. In 2006, there were 2000 ha of banana orchards on Gran Canaria, with an average water consumption of 9900 $\mathrm{m}^{3} \cdot \mathrm{ha}^{-1}$ year $^{-1}$ [4]. Nowadays, there are 1860 ha of banana orchards on Gran Canaria [19], with 
an average water consumption of $8200-9000 \mathrm{~m}^{3} \cdot \mathrm{ha}^{-1} \mathrm{year}^{-1}$ [20], although a higher consumption of $24,946 \mathrm{~m}^{3} \cdot$ ha $^{-1}$ year $^{-1}$ is allowed [21].

Banana (Musa acuminata) is sensitive to salt, with a salinity threshold of about $1 \mathrm{dS} / \mathrm{m}$ [22], demanding high water quality for irrigation [23]. Threshold Boron leaf contents for banana are $80 \mathrm{mg} / \mathrm{kg}$ (adequate content) and $300 \mathrm{mg} / \mathrm{kg}$ (phytotoxic level, [24]. Some sea water desalination plants for banana irrigation have been producing water using RO technology for 30 years in Gran Canaria Island. The aim of this study is to understand the long-term effects of ROW irrigation on B contents in banana orchards, which are also influenced by water and soil management.

\section{Materials and Methods}

The study was realized with water soil and leaves samples submitted by farmers from the banana region to the "Laboratorio Agroalimentario y Fitopatológico del Cabildo de Gran Canaria" and samples studied by the Soil Science Department from Universidad de la Laguna, Tenerife (Canary Islands) in 2006. During 2018, samples of water, soil, and banana leaves from orchards from the same area submitted to the laboratory by the farmers were analyzed and studied.

The studied region in Gran Canaria is situated near the NE coast, and is affected by the "Alisio" wind. There, the total annual precipitation is $243 \mathrm{~mm}$; the annual mean is $19.5^{\circ} \mathrm{C}$; and the lowest and highest monthly means are $16.9^{\circ} \mathrm{C}$ and $22.6^{\circ} \mathrm{C}$, respectively.

Banana orchards are usually drip irrigated; $3.5 \mathrm{~L} / \mathrm{h}$ emitters spaced $60 \mathrm{~cm}$ apart along the line is an example of irrigation system set up. The amount of irrigation water applied depends on the age of the plant. The amount of water applied slowly increases for 6 months until it reaches $90 \mathrm{~L}$ per plant per week in the winter and $100 \mathrm{~L}$ per plant per week in the summer [4]. Soil from the site is difficult to standard classify (Arent soils) due to the fact that the soil is transported to the sites from different parts of the island and deposited close to the coast for banana production. Soils are medium- to fine-textured, and slightly alkaline, with cation exchange from 30 to $35 \%$ and up to $2 \%$ of organic matter (OM).

Soluble B was determined from 56 water samples in 2006 and 30 samples in 2018 by inductively coupled plasma optical emission spectroscopy (ICP-OES), after a previous $0.45 \mu \mathrm{m}$ membrane filtration. Electric water conductivity (EC) at $20^{\circ} \mathrm{C}$ was also measured by a conductivity meter. Four water origins were considered: Water from Wells (WW) and Dam Water (DaW) (conventional resource), Blend Water (BW, mixing different water qualities before being sold to farmers), and ROW produced by RO Plants.

As B in soil solution is readily available for plant uptake, soluble B in saturated extract (BES) was determined from the soils of the selected orchards. There are different pools of $B$ in soil fractions that are in equilibrium with $B$ in soil solution. Hot water-extractable $B$ has been considered as a suitable index of plant-available B [25]. Therefore, hot water extraction method [26] was used for analyzing the data distribution of B soils determined in hot water (HWSB). Both BES and HWSB were analyzed by ICP-OES.

Andic soils from Tenerife were sampled in 2006 and determined by Soil Science Department (Proyecto BALTEN, 1994-2006). Boron in banana leaf (Giant and Dwarf Cavendish varieties) was determined by ICP, after a previous nitric acid digestion in microwave.

Statistical analysis was performed using the package SPSS 26.0 for Windows (IMB Corporation, Armonk, NY, United States). Groups of B content in water (mg/L) from the four water qualities are depicting using box plot through their quartiles. Program Generalized Linear Models (GLM )was used to compare EC $(\mathrm{dS} / \mathrm{m})$ and B $(\mathrm{mg} / \mathrm{L})$ in water and B content in leaves $(\mathrm{mg} / \mathrm{kg})$ and in soil $(\mathrm{mg} / \mathrm{kg})$, among the four water qualities studied; differences between means were tested using least significant difference (LSD) post-hoc tests with a level of significance $P<0.05$. Pearson correlations between (i) OM and B content in soil, (ii) B leave contents and B in water, and (iii) B leave contents and B in soil were determined. Scatter plots are drawn to show the results. 


\section{Results and Discussion}

In 2006, farmers used water of only two origins. Twelve years later, farmers are improving their water management and are blending water from different origins (Table 1). However, many farmers denominate water origin as the mayor component of the total blend. Therefore, DaW shows B contents higher than expected with regard to rain water (unique origin to DaW in Canary Islands); it is difficult to discriminate DaW from BW (Figure 1a).

Table 1. Electrical conductivity (EC) (dS/m) and boron (B) in water (mg/L), soils (mg/kg), and banana leaves $(\mathrm{mg} / \mathrm{kg}$ ) of four water origins considering two periods: 2006 and 2018, with Dam Water: DaW (conventional resource), reverse osmosis water (ROW) (produced by reverse osmosis (RO) plants), well water (WW), and blend water (BW) (mixing different water qualities before being sold to farmers).

\begin{tabular}{cccccc}
\hline Date & Water Origin & $\begin{array}{c}\text { EC Water } \\
(\mathbf{d S} / \mathbf{m})\end{array}$ & B Water $(\mathbf{m g} / \mathbf{L})$ & $\begin{array}{c}\text { B Soil (HWSB) } \\
(\mathbf{m g} / \mathbf{k g})\end{array}$ & $\begin{array}{c}\text { B Leaves } \\
(\mathbf{m g} / \mathbf{k g})\end{array}$ \\
\hline \multirow{2}{*}{2006} & $\mathrm{DaW}$ & $0.60 \pm 0.24^{\mathrm{a}}$ & $0.07 \pm 0.097^{\mathrm{a}}$ & $2.7 \pm 2.2^{\mathrm{a}}$ & $80-100$ \\
& $\mathrm{ROW}$ & $0.63 \pm 0.14^{\mathrm{a}}$ & $0.95 \pm 0.41^{\mathrm{b}}$ & $6.3 \pm 2.9^{\mathrm{b}}$ & $210-240$ \\
\hline \multirow{2}{*}{2018} & $\mathrm{WW}$ & $0.31 \pm 0.15^{\mathrm{a}}$ & $1.2 \pm 0.40^{\mathrm{bc}}$ & $6.8 \pm 1.5^{\mathrm{b}}$ & $64.00 \pm 11.94^{\mathrm{b}}$ \\
& $\mathrm{DaW}$ & $0.55 \pm 0.05^{\mathrm{a}}$ & $0.89 \pm 0.13^{\mathrm{b}}$ & $5.27 \pm 0.5^{\mathrm{b}}$ & $28.22 \pm 3.98^{\mathrm{a}}$ \\
& $\mathrm{BW}$ & $0.57 \pm 0.05^{\mathrm{a}}$ & $0.95 \pm 0.14^{\mathrm{bc}}$ & $5.21 \pm 0.5^{\mathrm{b}}$ & $38.12 \pm 4.22^{\mathrm{a}}$ \\
& $\mathrm{ROW}$ & $0.57 \pm 0.05^{\mathrm{a}}$ & $1.23 \pm 0.14^{\mathrm{c}}$ & $4.85 \pm 0.5^{\mathrm{b}}$ & $35.62 \pm 4.22^{\mathrm{a}}$ \\
\hline
\end{tabular}

abc Different letters in superscript following values indicate statistical significance.
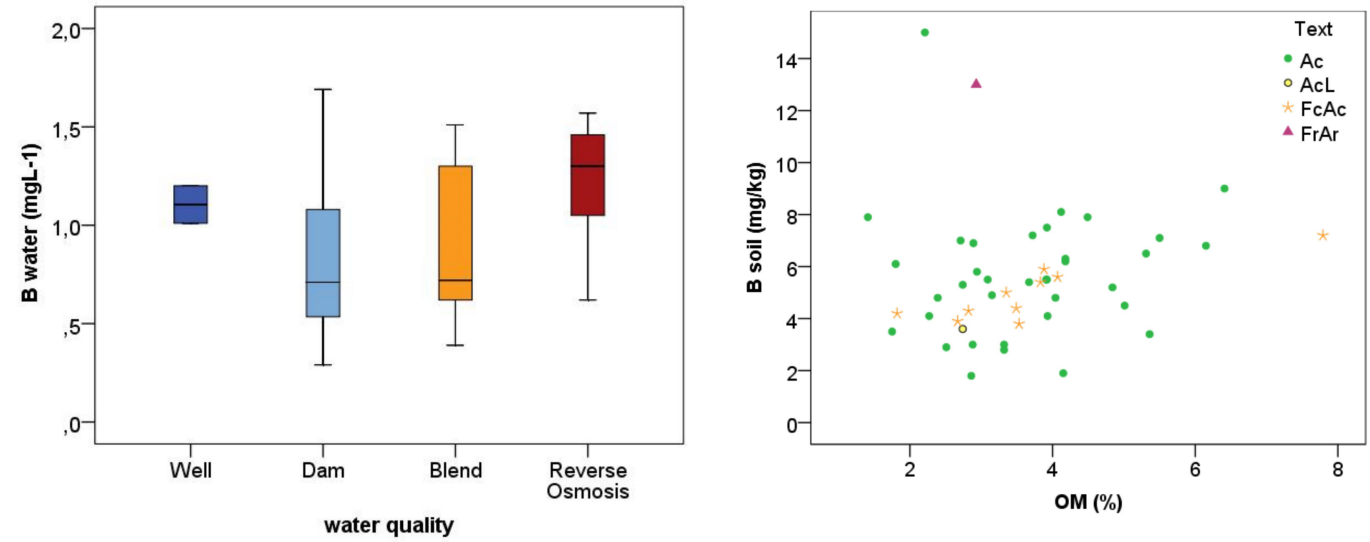

Figure 1. a (left) B concentration (mg/L) of the four water origins from 2018 and $\mathbf{b}$ (right) B in soil, data distribution of B soils determined in hot water (HWSB) $(\mathrm{mg} / \mathrm{kg})$ related to organic matter (OM) content (in \%).

Nowadays, as occurred in 2006, EC shows no significant differences among water origin (Table 1). $\mathrm{B}$ concentration is higher in all the water origins (Figure 1a), with ROW being significantly higher than DaW. WW and BW have the same B concentration as DaW. Therefore, all the water qualities fit into the risk interval defined by Ayers and Westcot [2]. As already mentioned, irrigation time period and soil retention capacity are considered in irrigation water quality standard for metals and metaloids [12,27]. The values in Table 1 show that B concentrations vary between the short- and long-range values of USEPA [12]. Irrigation water containing this level of B may not be immediately toxic to plants. Although the correlation is not significant, Figure $1 \mathrm{~b}$ depicts the relation between $\mathrm{OM}$ and B content in soil (HWSB), taking into account soil texture. Additionally, EC, pH, and clay content show no significant correlations with HWSB.

Banana region has soils with medium to high clay contents, is slightly alkaline $\mathrm{pH}$ [3], and OM level higher than $2 \%$, which contribute to B adsorption. Furthermore, the amount of B added by irrigation; other uncontrolled factors, such as calcium carbonate, Fe, and Mn oxides [28]; and soil moisture and 
temperature, are affecting the B content in studied soils. In 2006, B content in soils irrigated with DaW were significantly lower than those using ROW. After twelve years, soil B level irrigated by water from all origins (included DaM-irrigated soil) is the same as ROW soil in 2006. As previously mentioned by Nable et al. [13], after prolonged irrigation time with the abovementioned water qualities, B soluble levels in soil will increase. Figure 2 represents available data (2006) distribution of B soils vs. B content in Saturation Extract (BSE) in Gran Canaria, depending on the water quality applied: DaW and ROW. Lower values in saturated extract are found when irrigating using DaW than when using ROW. A significant buffer capacity characterizes some of the samples analyzed, because the very high values determined in soil do not necessarily correspond to high soluble B contents in saturated extract. On the other hand, high values of BSE, which could reach toxicity levels for plants, are found with moderate levels of HWSB when irrigating using ROW.

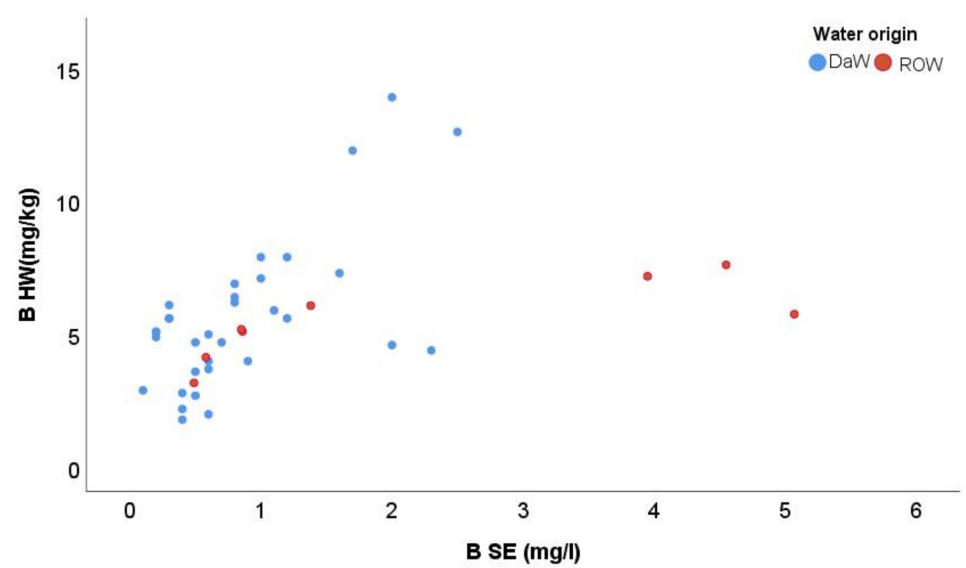

Figure 2. HWSB, in $\mathrm{mg} / \mathrm{kg}$, vs. B content in Saturation Extract (BSE, in $\mathrm{mg} / \mathrm{L}$ ) in Gran Canaria, depending on the water quality applied: DaW and ROW.

As mentioned, soil characteristics and water management modify B availability to plants [15]. In semiarid regions, low rainfall prevents natural leaching, and high water cost promotes the use of efficient water irrigation techniques, using low leaching fractions when low EC water is applied. Therefore, B accumulation on soil surface is a natural consequence of water management practices. Obviously, higher plant extraction levels will be associated with higher B contents in soil solution, until phytotoxic contents are reached due to the fact that B uptake is a passive process acting in response to mainly external boric concentration [29].

Table 1 shows the significantly lower B water concentration observed in 2006 for DaW, which significantly affected lower boron content determined in soil and in plant. These low levels are not found nowadays, as DaW has increased B concentration. It is noteworthy that plants irrigated with ROW in 2018 presented lower B concentration $(35.6 \mathrm{mg} / \mathrm{kg})$ than twelve years before $(210 \mathrm{mg} / \mathrm{kg})$, probably due to the better soil and water managements practices used by the farmers. In this sense, some amelioration methods used to reduce B risk with the use of soil amendments, such as lime or gypsum [13], and organic matter addition, are frequently used by banana farmers. This fact explains the low B content measured in leaves.

Only banana leaves irrigated using WW have significantly higher B contents $(64.0 \mathrm{mg} / \mathrm{kg})$ than plants irrigated by other water origins. This fact could be explained by WW tendency of having lower EC, probably associated with lower leaching fraction, and therefore higher B content in soils irrigated using this resource. In this sense, Pearson correlations between B leaf contents and B in water and B leaf contents and B in soil were significant (Figure 3a,b). 

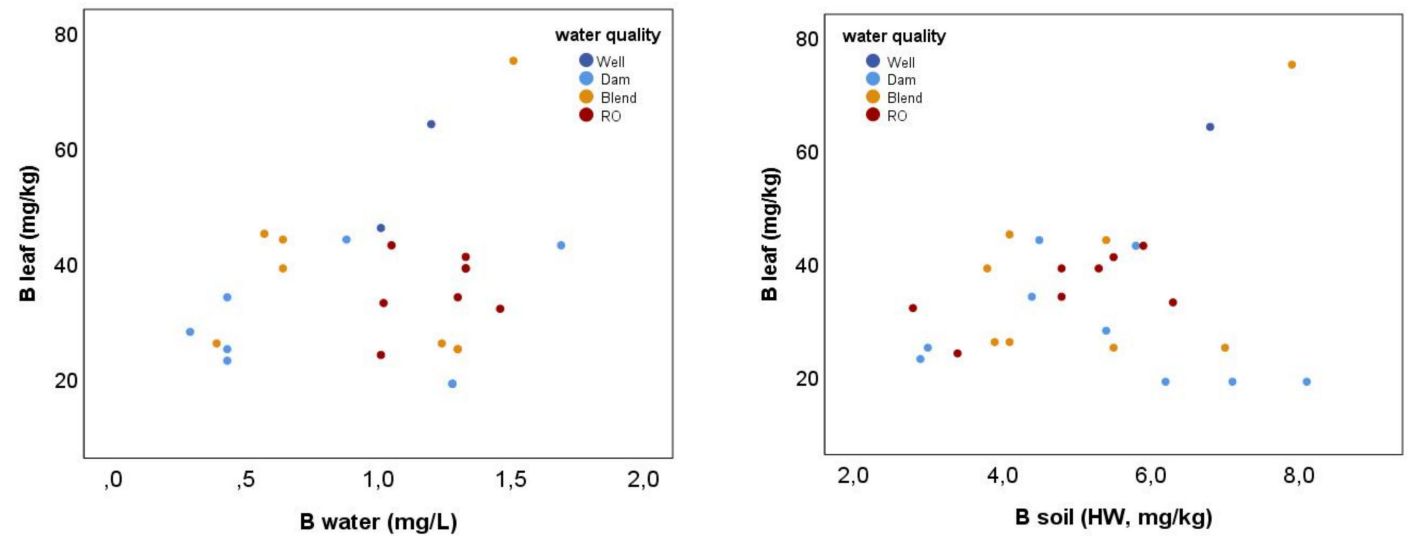

Figure 3. a (left) Relationship between B leaf (mg/kg) contents and B in water (mg/L) and b (right) B leaf contents $(\mathrm{mg} / \mathrm{kg})$ and B in soil (HWSB, $\mathrm{mg} / \mathrm{kg}$ ) irrigated with the four water origins.

Considering $9900 \mathrm{~m}^{3} \cdot \mathrm{ha}^{-1} \cdot$ year $^{-1}$ of irrigation water used and $0.95 \mathrm{mg} \mathrm{B} / \mathrm{L}$ in ROW, $9.4 \mathrm{~kg}$ $\mathrm{B} \cdot \mathrm{ha}^{-1} \cdot \mathrm{year}^{-1}$ was applied to the soil in the 2006 . Assuming a total dry matter yield of $22,000 \mathrm{~kg}$ $\mathrm{B} \cdot \mathrm{ha}^{-1} \cdot$ year $^{-1}$, and an averaged B content of $210 \mathrm{mg}$ per $\mathrm{kg}$ of dry matter in plant, only $2.2 \mathrm{~kg} \mathrm{~B} / \mathrm{ha} \cdot$ year would be removed by banana plant, representing $49 \%$ of the total added. Nowadays, considering the reduction of the water dosage to $9000 \mathrm{~m}^{3} \cdot \mathrm{ha}^{-1} \cdot \mathrm{year}^{-1}$ and from 0.9 to $1.2 \mathrm{mg} \mathrm{B} / \mathrm{L}$ concentration presented in almost all water samples, 8 to $11 \mathrm{~kg} \mathrm{~B}^{-h^{-1}} \cdot \mathrm{year}^{-1}$ are added to the soil. Assuming the same yield and an averaged B content of $33 \mathrm{mg}$ per $\mathrm{kg}$ of dry matter in plant, less than $1 \mathrm{~kg}$ $\mathrm{B} \cdot \mathrm{ha}^{-1}$.year ${ }^{-1}$ would be removed by banana plant, approximately representing $10 \%$ of the total added. Therefore, progressive accumulation should be expected in soil, although the HWSB seems to stabilize at the same values as the soils irrigated by ROW in 2006. Hence, HWSB apparently was not able to measure the mass of $B$ that accumulated during this studied period, which will probably be in other soil pools than those extracted using this method. On the other hand, this content of B in soil is higher than the value of $2-4 \mathrm{mg} / \mathrm{kg}$ described by Gupta [30], although greater values are mentioned by Nable et al. [13]. In this sense, abovementioned soil amelioration methods to reduce B risk could explain the low B content measured in banana leaves of the studied orchards.

Table 2 presents the results obtained in Tenerife Island in 2006, in which Andic volcanic soils were irrigated for near ten years using similar water management to that applied in Gran Canaria. As observed, although higher levels of HWSB in soil were obtained in Tenerife than in Gran Canaria, banana leaf contents are much lower. As previously mentioned, B adsorption is high in Andic soils due to the presence of aluminum and iron amorphous oxides [17]. This fact explained its low availability for plants and, consequently, the lower values obtained in foliar concentrations. Once again, soil and water management are critical factors to predicting the negative effect of B in banana production. Consequently, critical values for water quality must be revised if Andic soils are to be irrigated.

Table 2. B (mg/L) determined in Andic soils (mg/kg) and banana leaves (mg/kg).

\begin{tabular}{ccc}
\hline & B in Soil, HWSB $(\mathbf{m g} / \mathbf{k g})$ & B in Banana Leaves $(\mathbf{m g} / \mathbf{k g})$ \\
\hline Andic soils (Tenerife) & $6-12$ & $30-60$ \\
\hline
\end{tabular}

Although the HWSB content in soils seems to be stabilized after more than 30 years of ROW use (probably by the proper water soil and water management used by the local farmers), the calculated excess of $B$ applied by ROW related to that absorbed by plants raises the following questions: (i) is the hot water method used to determine B in soils adequate to estimate B risk in these soils?, (ii) is the use of another method that is able to determine B excess to assure sustainability necessary?, (iii) how long would be the safe period for irrigation in such conditions?, and (iv) is the critical concentration proposed by irrigation water quality standards $[12,27]$ useful for Canary Islands banana orchards? 
Another question arises related to the promotion of sustainable water management: what is the best option: to use membranes that are able to reduce B in ROW resources, to increase the leaching fraction, or to blend water of different origins?

Similar boron increase (determined both by hot water and in soil-water solution) was obtained by these authors irrigating with reclaimed water in forage production in Gran Canaria [31]. Thus, unconventional resources must be carefully evaluated both from risk and sustainability points of view to provide optimal management practices to the farmers.

\section{Conclusions}

No phytotoxicity has been observed in banana orchards of Gran Canary Island after a period of 30 years irrigating using ROW with B contents above $1.0 \mathrm{mg} / \mathrm{L}$. Although a progressive B accumulation in ROW irrigated soils should be expected, HWSB seems to have stabilized in the last twelve years. Therefore, the standard method of soil B measurement (HWSB) is not apparently able to measure the mass of $B$ that has been accumulating during the last 30 years. Careful management practices used by local farmers are probably preventing B phytotoxicity in a semi-arid region where low water resources are assigned for leaching purposes due to the high cost of water. In this sense, a question arises related to the promotion of sustainable water management: what is the best option: to use membranes that are able to reduce B in ROW resources, to increase the leaching fraction, or to blend water of different origins? Further studies must be done to answer this question, based not only on agronomic considerations but also in economic ones.

Author Contributions: V.M.-G., J.R.F.-V., J.M.H.M. and M.P.P.-D. had the original idea for the study. J.R.F.-V., were responsible for carried out the analyses, while V.M.-G., J.R.F.-V., J.M.H.M. and M.P.P.-D., were responsible for data cleaning and analysis. V.M.-G. and M.P.P.-D., drafted the manuscript, which was revised by all authors. All authors read and approved the final manuscript.

Funding: This research was funded by Ministerio de Economia y Competitividad (CGL2012-39520-C03-03) and Interreg MAC 2104-2020 Program (ADAPTaRES Proyect: http://adaptares.com/es/).

Acknowledgments: We are grateful to Laboratorio Agroalimentario y Fitopatológico del Cabildo Insular de Gran Canaria and to F. Fernandez (Consejo Insular de Aguas GC) for his valuable advices.

Conflicts of Interest: The authors declare no conflict of interest.

\section{References}

1. Jones, E.; Qadir, M.; Michelle, T.H.; van Vliet Smakhtin, V.; Kang, S. The state of desalination and brine production: A global outlook. Sci. Total Environ. 2019, 657, 1343-1356. [CrossRef] [PubMed]

2. Ayers, R.S.; Westcot, D.W. Water Quality for Agriculture; Irrigation and Drainage Paper 29, 1st revision; Food and Agriculture Organisation of the United Nations: Rome, Italy, 1985.

3. Palacios, M.P.; Haman, D.; Del-Nero, E.; Pardo, A.; Pavón, N. Banana production irrigated with treated effluent in Canary Islands. Trans. ASAE 2000, 43, 309-314. [CrossRef]

4. Palacios, M.P.; Fernández-Vera, J.R.; Hernández-Moreno, J.M. Sustainable Irrigation Using No Conventional Resources: Boron Phytotoxicity for the Future? In Proceedings of the International Symposium on Water and Land Management for Sustainable Irrigated Agriculture Libro de Actas, Adana, Turkey, April 2006.

5. Martinez-Alvarez, V.; Martin-Gorriz, B.; Soto-García, M. Seawater desalination for crop irrigation-A review of current experiences and revealed key issues. Desalination 2016, 381, 58-70. [CrossRef]

6. Ministerio de Agricultura, Pesca, y Alimentación (MAPA). Encuesta Sobre Superficies y Rendimientos de Cultivos. Informe Sobre Regadíos en España; N.I.P.O.001-19-051-9; MAPA: Madrid, Spain, 2018.

7. Consejo Insular de Aguas de Gran Canaria (CIAGC). Documentos Iniciales. In Ciclo de Planificación Hidrológica 2015-2021, Las Palmas de Gran Canaria: Consejo Insular de Aguas de Gran Canaria; 2016; Available online: http://www.aguasgrancanaria.com/pdfs/PlanHidro/PHGC-DOC-INICIALES-rev01.3.pdf (accessed on 24 May 2019). 
8. Consejo Insular de Aguas de Gran Canaria (CIAGC). Second Cycle of the Island Hydrological Plans (2015-2021), Documentos Iniciales del Tercer Ciclo de Planificación Hidrológica (2021-2027)—MEMORIA. Consejo Insular de Aguas de Gran Canaria. 2018. Available online: http://www.aguasgrancanaria.com/pdfs/ PlanHidro/ES120_GRAN_CANARIA_TERCER\%20ciclo\%20MEMORIA_20181115.pdf (accessed on 24 May 2019).

9. Henriquez, J.F.; Bonet, J.; Etxaniz, J. Galdar-Agaete seawater desalination plant construction and one year operational experience for the $3500 \mathrm{~m}^{3} /$ day RO plant. Desalination 1991, 82, 51-69. [CrossRef]

10. Gómez-Gotor, A.; Del Río-Gamero, B.; Prieto Prado, I.; Casañas, A. The history of desalination in the Canary Islands. Desalination 2018, 428, 86-107. [CrossRef]

11. Peñate, B.; García-Rodríguez, L. Current trends and future prospects in the design of seawater reverse osmosis desalination technology. Desalination 2012, 284, 1-8. [CrossRef]

12. U.S. Environmental Protection Agency (USEPA). Guidelines for Wastewater Reuse; EPA/625/R-04/108; US Environmental Protection Agency: Washington, DC, USA, 2004.

13. Nable, R.O.; Bañuelos, G.S.; Paull, J.G. Boron toxicity. Plant Soil 1997, 193, 181-198. [CrossRef]

14. Goldberg, S. Reactions of boron with soils. Plant Soil 1997, 193, 35-48. [CrossRef]

15. Goldberg, S.; Glaubig, R.A. Boron adsorption on aluminium and iron oxide minerals. Soil Sci. Soc. Am. J. 1985, 49, 1374-1379. [CrossRef]

16. Goldberg, S.; Glaubig, R.A. Boron and Silicon adsorption on an aluminium oxide. Soil Sci. Soc. Am. J. 1988, 52, 87-91. [CrossRef]

17. Arbelo, C.; Hernández-Moreno, J.M. Boron buffer capacity of andic soils irrigated with urban waste water. In Proceedings of the 16th World Congress of Soil Science Montpellier, Symposium 21, Montpellier, France, 20-26 august 1998; p. 43.

18. ASPROCAN. Cifras. Plátano de Canarias: Plátanos de Canarias. 2018. Available online: https: //platanodecanarias.es/asprocan-pdc/cifras/ (accessed on 17 July 2019).

19. ISTAC. Gobierno de Canarias. Canarias en Cifras. 2017. Available online: www.gobiernodecanarias.org/istac/ (accessed on 17 July 2019).

20. CIAGC. Plan Hidrológico de Gran Canaria. Ciclo de Planificación Hidrológica 2015-2021 Demarcación Hidrográfica ES 120 Gran Canaria. Consejo Insular de Aguas de Gran Canaria. 2019. Available online: http://www.aguasgrancanaria.com/pdfs/PlanHidro/ES120_PLAN_GC_firmado.pdf (accessed on 17 July 2019).

21. DECRETO 165/2015, de 3 de julio, BOIC núm. 134 de 13 de Julio de 2015 Instrucción de Planificación Hidrológica para las Demarcaciones Hidrográficas Intracomunitarias de la Comunidad Autónoma de Canarias. Available online: http://www.gobiernodecanarias.org/boc/2015/134/001.html (accessed on 17 July 2019).

22. Israeli, Y.; Lahav, E.; Nameri, N. The effect of salinity and sodium adsorption ratio in the irrigation water, on growth and productivity of bananas under drip irrigation conditions. Fruits 1986, 41, 297-302.

23. Wardlaw, C.W. Banana Diseases: Including Plantains and Abaca; Longmans: London, UK, 1961.

24. Reuter, D.; Robinson, J.B. Plant Analysis, an Interpretation Manual; Inkata Press: Melbourne/Sydney, Australia, 1986.

25. Goldberg, S.; Shouse, P.J.; Lesch, S.M.; Grieve, C.M.; Poss, J.A.; Forster, H.S.; Suarez, D.L. Soil boron extractions as indicators of boron content of field-grown crops. Soil Sci. 2002, 167, 720-728. [CrossRef]

26. Berger, K.C.; Truog, E. Boron determination in soil and plants. Eng. Chem. Anal. Ed. 1939, 11, $540-545$. [CrossRef]

27. Australian and New Zealand Environment and Conservation Council (ANZECC). Australian Water Quality Guidelines for Fresh and Marine Waters; National Water Quality. Management Strategy Paper No 4; Australian and New Zealand Environment and Conservation Council: Canberra, Australia, 2000.

28. Hou, J.; Evans, L.J.; Spiers, G.A. Chemical fractionation of soil boron: I. Method development. Can. J. Soil Sci. 1996, 76, 485-491. [CrossRef]

29. Hu, H.; Brown, P.H. Absorption of boron by plant roots. Plant Soil 1997, 193, 49-58. [CrossRef] 
30. Gupta, U.C. Boron deficiency and toxicity symptoms for several crops as related to tissue boron levels. J. Plant Nutr. 1983, 6, 387-395. [CrossRef]

31. Mendoza-Grimón, V.; Rodríguez-Martín, R.; Fernández Vera, J.; Palacios Díaz, P.; Hernández Moreno, J. Estudio de la disponibilidad del fósforo y boro aportados por las aguas depuradas en la isla de gran canaria: Metodología y resultados preliminares. In Estudios en la Zona no Saturada del Suelo; Álvarez-Benedí, J., Marinero, P., Eds.; Instituto Tecnológico Agrario de Castilla y León (ITA): Valladolid, Spain, 2003; Volume 6, pp. 355-359. ISBN 84-688-3698-2.

(C) 2019 by the authors. Licensee MDPI, Basel, Switzerland. This article is an open access article distributed under the terms and conditions of the Creative Commons Attribution (CC BY) license (http://creativecommons.org/licenses/by/4.0/). 